Rhode Island College

Digital Commons @ RIC

\title{
'Many Feign As They Are Dead": The Counterfeit Death in Romeo and Juliet and Much Ado about Nothing
}

Julie Bowman

Rhode Island College

Follow this and additional works at: https://digitalcommons.ric.edu/etd

Part of the Family, Life Course, and Society Commons, Feminist Philosophy Commons, Gender and Sexuality Commons, Literature in English, British Isles Commons, and the Women's Studies Commons

\section{Recommended Citation}

Bowman, Julie, "'Many Feign As They Are Dead": The Counterfeit Death in Romeo and Juliet and Much Ado about Nothing" (2007). Master's Theses, Dissertations, Graduate Research and Major Papers Overview. 14.

https://digitalcommons.ric.edu/etd/14

This Thesis is brought to you for free and open access by the Master's Theses, Dissertations, Graduate Research and Major Papers at Digital Commons @ RIC. It has been accepted for inclusion in Master's Theses, Dissertations, Graduate Research and Major Papers Overview by an authorized administrator of Digital Commons @ RIC. For more information, please contact digitalcommons@ric.edu. 


\title{
“MANY FEIGN AS THEY ARE DEAD”: THE COUNTERFEIT DEATH

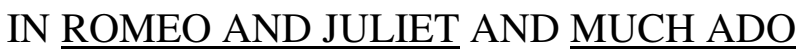 $\underline{\text { ABOUT NOTHING }}$
}

\author{
by \\ Julie Bowman

\begin{abstract}
A Thesis Submitted in Partial Fulfillment
of the Requirements for the Master of English

in
\end{abstract} \\ The Department of English
}

School of Graduate Studies

Rhode Island College 
“MANY FEIGN AS THEY ARE DEAD": THE COUNTERFEIT DEATH

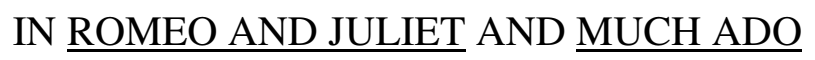

$\underline{\text { ABOUT NOTHING }}$

A Thesis Presented

by

Julie Bowman

Approved:

Committee Member Date

Committee Member Date

Committee Member Date

Department Chair Date

Dean, School of Graduate Studies Date 


\section{Acknowledgements}

This project owes a great deal to the Department of English at Rhode Island College. Specifically, I would like to thank my graduate committee, Dr. Pamela. J. Benson, Dr. Meradith McMunn, and Dr. Elisa Miller, for their participation and their excellent feedback on my project. I especially want to thank Dr. Pamela J. Benson, my thesis advisor, for her tireless reading and rereading of drafts, her ability to draw out my best ideas, and her constant encouragement. I could not have hoped for a more dedicated advisor or exemplary scholar with whom to work. She deserves all credit for the best parts of the project; any of its faults are my own. Special thanks to Patricia Brennan, the James P. Adams Librarian at Rhode Island College who provided assistance during the early stages of my research. To my friends and academic peers, Karen Pfeil, Dionne Irving, and Katy Howe, and my family, I want to express my appreciation for their enthusiasm throughout the project and their assistance with the final versions of the manuscript. And, finally, I want to thank my husband, Wade Kramm, for being the sounding board for my ideas and my best reader. None of this would have been possible without his support.

Julie Diana Bowman

Rhode Island College

May, 2007 


\section{Contents}

Introduction

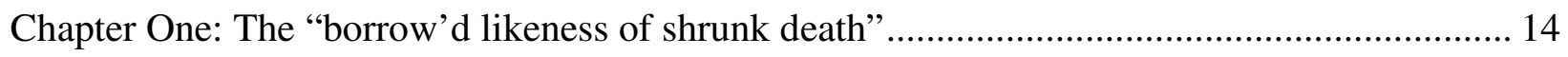

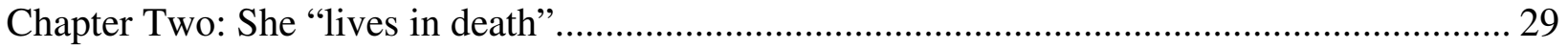

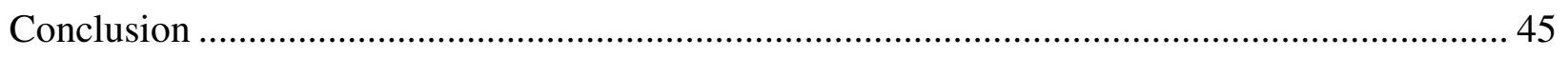

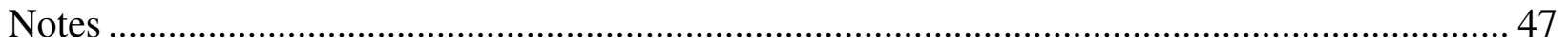

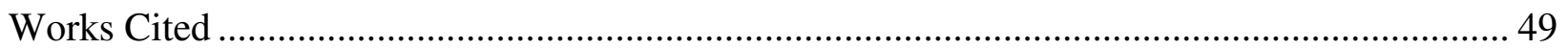


Bowman 5

"Many feign as they are dead ..."Juliet. Romeo and Juliet, 2.5.16 


\section{Introduction}

A young girl, to avoid an unwanted marriage, drinks a soporific cordial and, presumed dead by family and friends, is interred in a charnel house and revives forty-eight hours later. Another young woman, following a public repudiation at the marriage altar, faints and then circulates the rumor of her death to her former betrothed, hoping to change his mind about her. When he realizes her innocence, she revives, they are reunited and marry. These are not the bizarre headlines of grocery store tabloids. They are summaries of the counterfeit death sequences in Romeo and Juliet and Much Ado About Nothing.

The counterfeit death-when a character appears to be or is presumed dead by other characters and then returns to life-is a plot device used by Shakespeare, Marston, Webster, Jonson, Middleton, and others. It occurs in non-dramatic Early Modern works as well, such as the source for Romeo and Juliet, Arthur Brooke's long poem "Romeus and Juliet," and "Gonsales and his Vertuous Wife Agatha," an Italian tale by Barnabe Riche. John Marston's The Malcontent stages a series of counterfeit deaths to reveal the treacherous Mendoza, who has ousted Duke Altofronto and pursued the wives of Altofronto and Duke Pietro. Shakespeare uses the trope in one way or another in nearly every play with characters both male and female counterfeiting death. Falstaff, for example, feigns death in Henry V, Part I and hears Prince Hal memorialize him on the battlefield. In Antony and Cleopatra, Cleopatra sends word of her death to Antony to manipulate him and assuage his anger, but the news drives him to suicide. However, it would be a mistake to assume that Shakespeare's use of the trick, because of its recurrence, is just an easy solution to plot design or a sensational trick of the stage and nothing more. In Shakespeare's plays, it is more than a device to move along the plot, to protect a 
character, or even to surprise and delight the audience, though it often does all of these things as well.

Shakespeare's use of the counterfeit death and revival of the female character occurs frequently enough to merit special examination of the device's function for the heroine. Juliet counterfeits death in Romeo and Juliet; Hero in Much Ado About Nothing. Even Desdemona's brief revival after Othello has attempted to smother her can be counted as a supposed death and revival. Hermione's supposed death and revival in The Winter's Tale provides one of the most miraculous and startling reappearances of a female character following her counterfeit death. In some plays, Othello, for example, Shakespeare adds the event when it did not exist in the source material. In other plays, like Much Ado About Nothing, Shakespeare revises the story to assign the counterfeit to the female, rather than the male, character. These alterations indicate a deliberate authorial association of the device with the heroine and a comparative reading of the heroines' experiences reveals the ways in which the ruse benefits her character.

My reading considers in depth Juliet's counterfeit in Romeo and Juliet and Hero's in Much Ado About Nothing. For readers unfamiliar with the plays, or who have not focused on this particular plot element previously, I will begin by summarizing the counterfeit death in each play to expose the broad outlines of the progression of the trick and its significance. These two plays make excellent examples for a comparative analysis because of the genre difference and the tangible differences between the methods the heroines use to carry out the ruse. Despite these superficial differences, I will argue that the counterfeit deaths of the female characters in these plays are connected in two ways. First, each heroine's need to counterfeit death stems from concerns about her sexual purity. Second, counterfeiting death grants each heroine some power in that it enables her manipulation of her circumstances. Power cannot be thought of in this 
context as absolute authority, but rather as a type of agency. The feigned death functions as a strategy for coping with the limitations and strictures of her environment to achieve her particular end, either the marriage she desires or a declaration of her innocence. Thus, the act is not so radical as to free her completely from her social circumstances, but rather provides her with a means of resistance or defense.

Juliet feigns death to avoid her arranged marriage to Paris and free herself to leave with Romeo (whom she has already married). For the trick, she drinks a substance that gives her the appearance of death. She expects that when she wakes from this slumber, she and Romeo will leave Verona together. Juliet feigns death through physical means. Because she must ingest a substance to achieve the ruse, it directly involves her physical body and her inert body remains onstage in its "death."

Hero feigns death in order to re-establish her eligibility for marriage. Having accepted the marriage her father arranges for her, Hero is repudiated at the altar by Claudio, her fiancé, who thinks he has seen her being unchaste. She faints at Claudio's accusation and this action provides enough evidence to publish the rumor of her death, which is supported by the public pretense of her family and friends mourning her death. Hero's counterfeit death removes her physical body from the stage and she only appears onstage again in the scene that reveals the trick.

The significance of the trope has been the subject of critical scholarship, though not in the way that I am reading it. Those critics who have examined the trope's recurrent use, have not examined it from the perspective of the female character. In his important study, Shakespeare and the Comedy of Forgiveness, Robert Grams Hunter argues that the sub-category of the female counterfeit death in the comedies is a device that benefits the male character. Hunter considers the male protagonist's response to the female's counterfeit death in the comedies in light of 
medieval dramatic traditions and the denouement of forgiveness that restores balance. In Hunter's view the counterfeit death stems from an imbalance of love and hate in the male protagonist. Once the protagonist realizes his mistake, the woman's feigned death allows the full restoration of the relationship destroyed by his betrayal of love. Because Hunter's reading focuses on the male character, the female character and her experience become incidental, merely a means to an end. In addition, Hunter bases his argument about the function of the counterfeit death in a single genre, and so lacks a cohesive argument about the use of the trope across genres.

Robert A. Fothergill's comparative analysis of the counterfeit death trope in "The Perfect Image of Life: Counterfeit Death in the Plays of Shakespeare and His Contemporaries," compares Shakespeare's use of the trope to its use by Renaissance contemporaries such as Marston and Webster. In establishing the existence of a pattern, Fothergill does not consider any play a model example, but does consider Shakespeare to be a masterful playwright who uses the trope in a way that his contemporaries do not. In his comparison, Fothergill demonstrates that other playwrights use the trope as a trick that allows a male character to take revenge or to spy on his surviving heirs, whereas Shakespeare uses the trope to bring about "the penitential bereavement of the man who believes himself responsible," a conclusion similar to Hunter's (169). Again, the focus remains on the implications for male character.

Surprisingly, feminist critics have not already seized on the lack of scholarship considering the important role that the counterfeit death plays for the female characters. Some critics have dealt in passing with the feigned death in a single play. These readings tend to view the need to counterfeit death in negative terms and as evidence of an oppressive social structure. Carol Cook's interpretation in “'The Sign and Semblance of Her Honor”: Reading Gender 
Difference in Much Ado About Nothing" is typical. She reads Hero's counterfeit death as the "ritual resolution that reasserts Messina's stability without the need for painful questioning" of its gender roles and attitudes (198). As in Hunter's and Fothergill's readings, Hero's fictional death serves the other characters and is understood as a means of restoring order. Cook objects to the restoration of the patriarchy. She argues that through the death the men see Hero as "cleansed of carnality, of the blood that has been read as the sign of sexuality and guilt ... so that the fluid, vital, ambiguous text of her face will be replaced by a petrified monument to her virginity" (197). Readings such as Cook's present the heroines' counterfeit death in negative terms. I suggest that Hero's "death" restores her to life and to the marriage that was interrupted by the repudiation, thus the effectively ending her virginity, rather than perpetually memorializing it.

By focusing particularly on the counterfeit death for the female character, the reasons she orchestrates it, and what it accomplishes for her in particular, my reading corrects this oversight by feminist critics. At the same time, it builds on the insights of feminist criticism. It is a curious contradiction that by counterfeiting death, essentially becoming inert and inactive, women exert some influence. Lisa Jardine identifies a similar paradox in Gertrude, noting that "she is guilty by virtue of her power to disrupt the patriarchal power structure in spite of her actual passivity" though Jardine does not recognize the same power in passivity in Hero (93). In a similar way, the feigned death allows the heroine to assume an apparent passivity in order to gain the ability to exercise personal power.

To position my work within existing feminist Shakespearean scholarship, I will now outline the progression of feminist readings of Shakespeare and then situate my argument within this critical approach. Female readers through the ages have reacted to Shakespeare's plays with affinity or aversion, arguing over his cultural capital, the construction of the female characters in 
his plays, the qualities of femininity, and the social strictures of Early Modern English society. The female reader of Shakespearean has existed as long as Shakespeare's plays themselves. In fact, a woman, Margaret Cavendish, has the unique distinction of being named "the first Shakespeare critic" (Romack 25). Although women have engaged with the plays since their inception, what we currently understand as feminist criticism of Shakespeare developed during the 1970s.

Early feminist scholarship on Shakespeare was not necessarily "feminocentric," but it did pay "acute attention to the woman's part in literature" and in doing so it examined patriarchy, gender stereotypes, and genre in relation to the woman (Lenz 3). As the feminist readings of Shakespeare developed, the approach to his text became more fragmented. In 1983, Lisa Jardine identified two approaches, one that assumed Shakespeare's female characters "reflect accurately the whole range of specifically female qualities" and another which assumed that "Shakespeare's society is taken to be oppressively chauvinistic" $(2,3)$. Jardine rejected both of these assumptions and paved the way for another approach feminists could bring to Shakespeare. She used "specific cultural issues of the early modern period" to "provide useful perspectives on the treatment of women in the drama" (6). A cultural approach to Shakespeare remains relevant, but as our understanding of culture has expanded to include women representing themselves, recent feminist scholarship on Shakespeare has been complicated by attention to non-canonical and female writing. Dympna Callaghan observes that, as a result of interest in women's writing, feminist Shakespeareans have had to actively justify the work they do with a canonical male writer. Callaghan describes contemporary feminist Shakespeareans as not just "purely literature scholars but as cultural historians who are especially interested in women's own representation 
of themselves" (xiv). In other words, we can also use cultural materials to see how Shakespeare represents women representing themselves.

My examination of the counterfeit death engages one of the most fundamental principles of feminism by examining an overlooked aspect of Shakespeare's play and focusing particularly on the woman's part in that trope. Like other contemporary feminist Shakespeareans, I also turn to relevant cultural documents and literary antecedents and analogues to illuminate the trope I am studying. Broadsheets, pamphlets, marriage dispute cases, and death studies research help make clear how the counterfeit death is possible and useful for these characters. A marriage dispute case helps us understand the limitations these characters faced in managing their lives. Broadsheets and pamphlets and research about burial and mourning practices reveal why a feigned death and revival is conceivable, and believable, in life and not just a stage trick. Antecedents and analogues demonstrate the deliberate authorial decisions that granted the use of the trope to the woman to accomplish her particular task. In conjunction with a close textual reading of the plays, these cultural materials reveal the importance of the experience for the character who undertakes it.

In chapter one, I examine Juliet's willingness to take on death by examining Shakespeare's development of Juliet's character from the source character he inherited. This reveals how his Juliet is a more independent character. Then, I use cultural materials from Early Modern England to show that Juliet's counterfeit death reinforces her construction as an independent character. In this chapter, it becomes apparent that the Juliet's use of the trope is culturally believable and purposefully undertaken for the benefit of her character.

In chapter two, I advance a reading of Hero's character that goes against the grain of most critical readings of her character. I suggest that Hero actively fashions a specific identity 
Bowman 13

and, like Juliet, counterfeits death with the intention of achieving marriage. I rely on the source story and an analogue to establish Hero's activity as a heroine and cultural materials to develop the idea that Hero consents to the counterfeit death and that she intends it to reaffirm the truth about her chastity. 
Chapter One: The "borrow'd likeness of shrunk death"

From the chorus's opening prologue, vivid and insistent death talk pervades $\underline{\text { Romeo and }}$

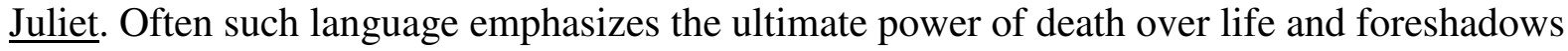
the play's tragic ending; however, it would be a mistake to rush to the end of the play and ignore Juliet's attempt to counterfeit death to avert the impending tragedy. Juliet's feigned death is significant in Shakespeare's oeuvre because it is one of the earliest instances of the device in Shakespeare's work and, in some ways, one of the most developed uses of the trope, perhaps because of its centrality in the source poem. Examining Juliet's feigned death experience first reveals the centrality of sexual purity in the experience, exposes the legal and social limits that the female character tests through her behavior, and establishes a framework for understanding the evolution of the counterfeit death in subsequent plays. Shakespeare imagined Juliet's experience in emotional terms and gave her a great deal of agency in the act. Though the Friar suggests the ruse, it requires Juliet's "valour in the acting it" (4.1.120).

In this chapter, I will begin by establishing Juliet's character as Shakespeare develops it from the source poem, Arthur Brooke's "Romeus and Juliet," ${ }^{1}$ to demonstrate the ways in which the play's Juliet is a determined and willful heroine. Then, I will establish the necessity of the trick for Juliet in light of marriage laws and adultery. I will then examine mourning and burial practices in the period in relation to Juliet's counterfeit death, the mourning, and preparation of her body, and the absence of embalming, which makes the trope a viable alternative for the character and the believable to the audience.

The plotting of the counterfeit death in the play matches that of Brooke's poem. In both the play and the poem, the counterfeit death temporarily provides some relief to the mounting tension brought about by Romeo and Juliet's secret marriage, Romeo's fatal dual with Tybalt, 
Romeo's banishment, and Capulet's arrangement of Juliet's marriage to Paris, and gives the audience, as well as Juliet, hope that a tragedy might yet be averted. In the play, the trick occurs in Act four, and, as portrayed in the source poem, Juliet goes to see the Friar after her parents tell her of her impending wedding to Paris. The Friar provides the plan and the means to escape the second marriage. In terms of plot, the trope is a potential means of overcoming a complication and achieving a comedic, instead of a tragic, resolution.

Although the same trope exists in the source poem, there are subtle variations between the source and the play that provide insight into Juliet's character and the issues touching the counterfeit death. The play's Juliet is an active heroine. She owns the counterfeit death as a strategy much more than her source character. The poem's Juliet goes to the Friar for shrift and reveals her situation there. At the end of her confession, she tells the Friar her resolve to kill herself to avoid the second marriage and frames her suicide as necessary to avoid other sins:

'Once was I wedded well, ne will I wed again;

For since I know I may not be the wedded wife of twain,

For I am bound to have one God, one faith, one make,

My purpose is as soon as I shall hence my journey take,

With these two hands, which joined unto the heavens I stretch,

The hasty death which I desire, unto myself to reach.

This day, O Romeus, this day thy woeful wife

Will bring the end of all her cares by ending careful life.

So my departed spirit shall witness to the sky,

And eke my blood unto the earth bear record, how that I

Have kept my faith unbroke, steadfast unto my friend.' (Brooke 2019-2020) 
Notice the religious language of the poem's Juliet. She is bound by God to have one husband. She will end her life to bear witness to her steadfast faith to her first marriage. She expects and asks for no other alternative from the Friar, though she frightens him with her words. He leaves her to contemplate the situation and then returns with the solution: counterfeit death. The play's Juliet shows greater expectation of a solution. Her lines preceding her visit to the Friar indicate that she seeks him to "know his remedy" (3.5.241). When she arrives, the Friar has already heard of the scheduled marriage to Paris and she responds, "Tell me not, Friar, that thou hearest of this, Unless thou tell me how I may prevent it.” (4.1.50-51). She expects to receive instruction from the Friar about how to prevent the marriage and, though she arrives at the Friar's with a knife, she is not resigned to committing suicide, unless "all else fail" (3.5.242).

In the play, the issue of the sin of a second marriage, so important in Brooke's poem, recedes to the background. The play's Juliet does not object to it in terms of sin, but rather views it as problematic in terms of her own desire. She refers to her marriage to Romeo more often in terms of love than of duty. Her heart is joined to Romeo's and her "true heart" will not "turn to another" (4.1.58-59). She wants to be married to Romeo; she does not want to marry Paris. The poem's Juliet speaks of literal suicide as a means to bear witness to her unbroken faith and steadfastness to her marriage. In the case of the poem, the loyalty appears to be to the idea of marriage, not to the particular marriage to Romeo. Both characters accept the task of feigning death in order preserve the first marriage, but the play's Juliet acts more from her own desire for the marriage to Romeo than from a sense of duty to spiritual laws of matrimony. The distinction in the characters is a subtle one, but important to my reading of this counterfeit death. The play's Juliet demonstrates greater agency; she chooses her mate, arranges their marriage, and then feigns death to preserve it. 
Because Juliet's first marriage was a clandestine one, its preservation without the counterfeit death could have been complicated and time-consuming. Understanding more about clandestine marriages will help clarify the complexities of Juliet's predicament and perhaps show why other possible solutions to her dilemma, such as confessing her first marriage to her parents or simply running away, are not considered by the characters. Juliet has two problems. First, if she marries again, she will dishonor the first marriage. Second, she contracted a marriage without her parents' consent. Could she just reveal the marriage to her parents instead of staging an elaborate counterfeit death to escape? What might the consequences have been? Because her first marriage lacked parental consent, Juliet could have been publicly shamed and excommunicated. Her parents, or the Montagues, could have contested the marriage in court, which at the very least would have resulted in the continued separation of the couple pending the case, and, at worst, might have annulled the marriage.

Documentation of a marriage dispute case that resembles Romeo and Juliet's situation reveals some of the complications that Shakespeare could have counted on his audience knowing a woman in Juliet's situation might have faced. The clandestine marriage of Maria Audley and Thomas Thynne in 1594 provides some insight into the risks of a secret marriage. In "For Love, Money, or Politics? A Clandestine Marriage and the Elizabethan Court of Arches," Allison Wall describes Thomas and Maria's marriage, its motives, and the resulting court case. Like Juliet and Romeo, Maria and Thomas were young, perhaps sixteen. They married with the approval of Maria's parents, but not Thomas's, and then kept their marriage secret for a period of time because the families were political enemies. Wall notes that "[m]atrimonial litigation could spring from parental opposition, especially after clandestine marriage, but it was quite rare" ${ }^{22}$ and yet, once Thomas's father learned of the marriage, he pursued a six-year suit to have the 
marriage annulled (531). The marriage was finally ruled valid when Thomas confessed the marriage in private to the dean of the Arches (528). If Juliet confessed her marriage to Romeo to her parents, she might have risked all of the possibilities that Wall suggests for Maria and Thomas: her parent's anger, public shame, excommunication, annulment, and disinheritance.

Clandestine marriages were not encouraged, though it is clear from the marriage of Maria and Thomas that they did occur and could be upheld by the law after the fact. The arrangement of the marriage to Paris puts additional pressure on Juliet's situation; her secret marriage may now result in adultery. Henry Swinburne, a Prerogative Court judge, explicates the gravity and complexity of the situation in "Treatise of Spousals or Matrimonial Contracts (1686)." 3 Swinburne explains that secret contracts "are not good" and that the law forbids them because of several inconveniences that may result (290). One of the problems Swinburne identifies is the difficulty of proving the validity of secret contracts should one member of the party break the contract. The Nurse is perhaps correct in suggesting that Juliet could marry Paris and Romeo would not return to challenge her:

Romeo is banish'd, and all the world to nothing

That he dares ne'er come back to challenge you.

Or if he do, it needs must be by stealth (3.5.213-5).

If the Nurse is correct, then the second marriage poses no threat to Juliet's public reputation. No one would know that she was an adulteress.

By threatening her marital fidelity, the second marriage makes purity of the female body a central issue. Even if Juliet could marry again and not be challenged, Swinburne advises those who are clandestinely married to "not marry any other person; for doubtless [the second marriage] is thy pretended marriage, how lawful soever it may seem in the eye of man, who 
judgeth only according to outward appearance, is nothing, but mere adultery in the infallible sight of God's just judgment" (291). Juliet takes this position as well, rejecting the Nurse's advice, saying it is "more sin to wish me thus forsworn" (3.5.236).

Juliet uses this argument against sinning more as a convenience. It matches what she wants, and is therefore useful to her. There is evidence that she sincerely desires to remain pure, "[t]o live an unstain'd wife to my sweet love," but it is not clear whether we can confidently take her words at face value (4.1.88). She does not seem overly concerned with obedience and sin elsewhere. Throughout the play her actions are self-serving. She even speaks dishonestly on occasion. For example, after resolving on the plan to counterfeit death, Juliet tells her father that “[h]enceforward I am ever rul'd by you,” when she has no intention of obeying him and marrying Paris (4.2.22). She successfully reinterprets laws for her own benefit. Her mother tells her to "think of marriage now" and directs her specifically toward Paris (1.3.69). Juliet obeys in the first part, but not the second. Even her resolve to commit suicide raises interesting questions about her fear of sinning. The revision of her resolve to "myself have power to die" from literal suicide to counterfeit death also represents a kind of partial obedience for convenience. In each case, the play portrays Juliet's independence by allowing her character to be governed more by her own desire than by a sense of duty to the laws of God or man.

Juliet's decision to counterfeit death demonstrates her intention to continue to control the direction of her life on her own terms. Instead of confessing to her parents her reason for her vehement refusal of the marriage to Paris, thus moving the control to them and perhaps being forced into legal battles to have the marriage dissolved (as Maria and Thomas), Juliet continues to act on her own. Once her mother and father leave her with an ultimatum to shape up, Juliet turns to those individuals in her life who know her secret, first to the Nurse, who, to Juliet's 
chagrin and dismay, encourages her to marry Paris, and then to the Friar. It is the Friar who offers a solution, but it is Juliet who pushes him to that extreme.

With the potion provided by the Friar, Juliet can take control of her situation by taking on the image of death. It is a bold move. Not many characters before her, male or female, have been so brazen, and few have used a potion like the Friar's on themselves. In “"A Thing Like Death':

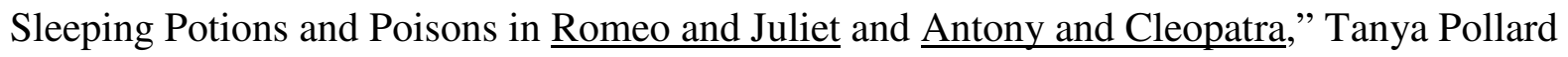
cites several other contemporary plays that rely on a false poison to produce a death-like sleep, including Marlow's Jew of Malta, Edward Sharpham's The Fleire, John Day's Law Tricks,

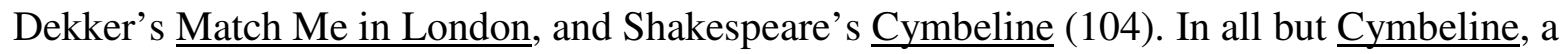
male character uses the potion and, in all but the Jew of Malta, the character uses it on someone else, not him or herself. Juliet uses the potion to preserve her marital fidelity. In this way, she acts for Romeo as much as for herself. As I demonstrated earlier, Juliet does not concern herself as much with the notions of sin that may be relevant to her situation, but acts from her own desire. She does not commend herself to God, but to her husband: "Romeo, Romeo Romeo, here's drink! I drink to thee" (4.3.58). Her deathbed language reinforces the pre-eminence of Romeo as her reason for acting. Thus, the counterfeit death becomes a way to continue the first marriage and avoid the second marriage, though there is no indication that the intent is to remove the couple until the truth can be revealed and the families reconciled. The Friar's plan is for Juliet to leave for Mantua with Romeo; there is no discussion of returning. Thus, the counterfeit death is a means of escaping an unpleasant situation and maintaining control of her marriage choice. 


\section{II}

Though modern burial practices may make modern audiences see Juliet's plan as impossible, embalming was not yet a common practice, thus intact bodies were prepared and buried or entombed within a few days. Revival of the supposedly dead was possible. Some period records indicate a period of watching the body until it was interred. In $\underline{\text { Birth, Marriage, \& }}$ Death, David Cressy describes the reasons for this practice as having multiple purposes, ${ }^{4}$ one of which "was to have someone on hand in case the body unexpectedly revived" (427). To an Early Modern audience, then, Juliet's counterfeit death ruse is practically feasible. There are seventeenth-century accounts of the miraculous revivals of the dead. One such account, "A Full and True Relation of a Maid (1680)," published as a broadsheet, is interesting for three reasons: first, it confirms the possibility of the revival of an apparently dead woman; second, it suggests the possibility of the "death" as a method of escape from an unpleasant situation; and third, it demonstrates the theatricality of such an event.

The broadsheet describes the death and revival of a Grace Ashburne who was buried in London on December $27^{\text {th }}$ and revived four days later. She was disinterred after she "was heard by several Neighbors most lamentable to Groan and Cry out in her Grave, to the great Astonishment of the Neighborhood." The report indicates that she was warm, breathing and had "a Colour as fresh as a Rose." She seems to have revived for only a few hours and was then returned to her Christ-Church Hospital grave. The event was startling to the community, so obviously not a common occurrence, but it does indicate the possibility of misdiagnosing death and the preparation of bodies (or lack thereof) that would allow for the possibility of the revival of a supposedly dead body. 
In addition to suggesting the possibility of revival, Grace's story also suggests that the death and revival can be used as a method of escape. In addition to testifying to her warmth, breath, and color, the broadsheet also describes bruises and scars on the her body, allegedly from the physical abuse of the master and mistress to whom she was apprenticed. The author declines to judge whether this abuse "hastened her end, or shortened her days," yet the text seems to imply that her revival was pivotal in identifying the abuse by the couple and even that Grace may have welcomed her death as an escape from a difficult situation. The broadsheet reports that Grace "many times hath in the hearing of several, wished her self Rather to be buryed alive, than to live under such hard and severe usage" (original emphasis). I do not mean to suggest that Grace counterfeited death intentionally, as Juliet did, but the desire to use death as a means of escape, coupled with the coincidence of her revival is remarkable and demonstrates that such a ruse could be conceived of as a method of escape. For women without many options for exercising independence, a counterfeit death to remove one's body from an abusive situation might be an appealing option. The act is fairly passive, yet might have been perceived as granting the woman the liberation she seeks.

Grace's story has one final resemblance to Juliet's. Grace's revival shows the dramatic potential of such an event. The counterfeit death as it occurs in the plays is an unquestionably theatrical element, but in both Romeo and Juliet and revival of Grace Ashburne, the spectacle of the female body and its condition are crucial. Following her revival, Grace was "exposed to publick view for several Hours, at a penny a piece Charge" and "some Hundreds of Spectators" viewed her body. This display not only demonstrated the restoration of life, but also the marks of abuse that the anonymous reporter referred to in the broadsheet. 


\section{III}

The relationship of the counterfeit death to the expectations for actual death further illuminates the significance of the experience for Juliet's character. There are three main areas to examine: the deathbed, the lamentations, and the burial. In the play, all three areas deviate from our expectations in a way that reinforces Juliet's independence. At the earliest stages of the counterfeit death, the play departs from the communal aspects of death practices during the period. In general terms, the period preceding death was to be used to resolve both material and spiritual matters. In Death in England, Clare Gittings writes that "[d]ying is a public spectacle in a crowded room, governed by its own code of conduct" (154). David Cressy concurs. In Birth, Marriage, \& Death, he explains that the dying "would rarely face [death] in isolation. Ideally, according to Christian counsel, the death bed would be attended by ministers and friends, neighbors and kin, who would share godly comfort and bear witness to a satisfactory passing" (390). Juliet faces her experience alone, though she does still act out the process of bidding goodbye to loved ones. Juliet recognizes that the Friar may not be telling the truth about the potion. If so, she may actually die when she begins the process of pretending death and, like someone who is ill anticipates his or her death and is able to bid farewell to those gathered with them, Juliet bids farewell to her family and the Nurse at the beginning of her counterfeit death bed speech:

Farewell. God knows when we shall meet again.

I have a faint cold fear thrills through my veins

That almost freezes up the heat of life.

I'll call them back again to comfort me. (4.3.14-17)

The speech works as a farewell to those whom she will be leaving and whose earthly path she may not cross again. It reads equally well as bidding farewell to loved ones in this temporal life, 
as only God knows the time of death when they may be reunited. And yet, just as Juliet begins in obedience to her parents, promising to "look to like" and then rejecting the man her father has selected for her, she begins and then rejects the traditional death bed scenario (1.3.97). She begins her speech to bid farewell and even to desire the comfort of the presence of those she has sent way, but then resolves "My dismal scene I needs must act alone" (4.3.19). Juliet faces her (counterfeit) death alone, without the comfort of the Friar, the Nurse, family, or friends.

Mourning, like the death bed performance, also had guidelines for appropriate behavior. With changes in the religious orientation of England under Protestantism, mourning practice changed as well. No longer could the living perform any rites to intercede on behalf of the soul of the deceased. Instead, the death of a loved one became an opportunity to examine one's own spiritual state. The theme of Thomas Playfere's sermon, The Meane in Mourning, delivered in London in 1595 illustrates the change in mourning ritual under Protestantism. Drawing on Christ's words to his mourners "weepe not for me, but weep for yourselves," Playfere argues that "to weep for your selves is lawful: to weep immoderately for Christ is unlawful" (3, 108-109). By extension, weeping for the dead, who have attained the glory of God is unnecessary. The dead, if they could return would advise the living to also weep for themselves because the living "yet remaine in this vale of misery, where [they] sinne daily and hourely against God, where continually [they] feel afflictions and punishments due to [their] sins" (83).

The Capulet family and Paris weep for themselves when they discover the apparently dead Juliet; however their lamentations address their earthly loss not their spiritual state. Capulet's mourning focuses on his own loss; however, his focus seems to be on his own loss of an heir, rather than his loss of a daughter. Thus, the language of the lamentations superficially suggests that Capulet mourns the loss of his daughter while it simultaneously reinforces Juliet's 
independent character. He laments, "Death is my son-in-law, Death is my heir; My daughter he hath wedded" (4.5.38-39). In "Rhetoric and the Rehearsal of Death: the 'Lamentations' Scene in Romeo and Juliet," Thomas Moisan deconstructs the "lamentations" scene to reveal what the rhetoric of the scene attempts to conceal, namely its insincerity and duplicity. The characters fail to connect with Juliet or with each other. In interpreting Capulet's response to Juliet's death, Moisan describes Capulet as the "aggrieved patriarch" who sees "Death as a rapist and a most unsavory, and unwelcome, son-in-law, who by stealing Juliet away, has deprived him of the right to choose an heir" (392). Moisan also describes the other characters' reactions, but I want to remain focused on the hidden ironies in Capulet's language because of the role of the fatherdaughter relationship in arranging marriages during the period.

Reading Capulet's speech during the lamentations scene from the vantage point I've assumed for this argument extends Moisan's observation of what the language conceals. Capulet's words distract from the fact that he laments what he never possessed. Unbeknownst to Capulet, he had been deprived of the right to choose an heir before he began to arrange Juliet's marriage in earnest. It was Juliet who assumed that responsibility for her father. The audience, aware of the ruse of her apparent death, knows that it is not Death that has stolen Juliet, but Juliet herself.

At the end of the scene, it is the Friar who returns the mourning to the direction outlined by Thomas Playfere in The Meane in Mourning. The Friar scolds the family for focusing on the worldly:

And weep ye now, seeing she is advanc'd

Above the clouds, as high as heaven itself?

O, in this love you love your child so ill 
That you run mad, seeing she is well. (4.5.73-76)

The Friar has the advantage of knowing Juliet has not truly died; however, his speech alone remains in line with the cultural evidence of mourning practice. He even articulates the Protestant belief that one is immediately taken to heaven, though the setting and his character would have held the Catholic belief in Purgatory. Because the phrasing actually suggests that Juliet is as high as heaven, a less literal religious reading might suggest that the advancement the Friar refers to is Juliet's ability to rise above he family's hatred enough to love and marry an enemy, which reinforces our sense of Juliet's ability to act on her own initiative and resolve.

\section{IV}

Juliet's ability to feign death relies on the way bodies were handled in death during the period. Not only is Juliet not buried—she is placed in the Capulet tomb—which prevents suffocation of a live "corpse," but she is not embalmed. The believability of the Capulet treatment of her corpse, entombing without embalming, is critical to the function of the plot trick and reinforces the moral reasoning for her action. Embalming knowledge existed, but its use was rare. It was especially uncommon for women to be embalmed. The gendered attitudes towards embalming bring our focus back to the issue of the purity of Juliet's body and her effort to maintain it.

Preoccupation with purity motivates the female preference to remain intact even as a corpse. In Women, Death, and Literature in Post-Reformation England, Patricia Phillippy examines the gendered difference in embalming practice. Many women, including Queen Elizabeth, left instructions that they not be embalmed. Phillippy explains that "Elizabeth's resistance to embalming was typical of the growing distaste among noblewomen for the practice and the perceived vulnerability of the female body before its invasive scrutiny" and that 
Elizabeth's request to not be embalmed may have been "prompted by a desire to protect her corpse from male penetration" (55, 57 original emphasis). Phillippy writes that "women's recorded desires to avoid opening seek to protect their chastity even in death, and thus attribute to the dead flesh the remnants of living morality and reputation" (57). The purpose of Juliet's counterfeit death is to maintain her fidelity to her marriage to Romeo. The general absence of embalming makes the counterfeit possible. The gendered position of embalming practice emphasizes Juliet's unwillingness to be penetrated by any other man. The Friar is present to make sure that the audience understands that the Capulets will not embalm Juliet's body. The Friar tells the family (and the audience) how the body will be prepared:

Dry up your tears, and stick your rosemary

On this fair corse, and, as the custom is,

All in her best array bear her to church. (4.5.79-81)

From these lines, it seems clear that Juliet will be entombed quickly, which was practical to avoid the decay of an intact corpse and, in this case, essential to complete the ruse because she would awaken in 42 hours.

Is Juliet's counterfeit death a success? Due to circumstance beyond her control, the trick does not bring about the reunion in life that she desires, but it does have positive impact on the community. The tragic ending for the lovers in no way diminishes the valor of her attempt and the expression of her own power to pursue her own desires that the ruse reveals. Robert A. Fothergill admits that "it is impossible not to feel that the tragic accident of Romeo's ignorance and mistiming is connected with the sacrilegious hazard of Juliet's attempt," which suggests a sense of punishment for her boldness, but then concludes that the ultimate death of the lovers is not "the penalty for adopting a forbidden course" (170). Fothergill correctly identifies qualities in 
Juliet's character that motivate her independence: a strong passion, and willingness to act on her own behalf. The counterfeit death is a culminating act of independence for Juliet. It is hoped that the outcome will justify the action. As the Friar suggests:

For this alliance may so happy prove

To turn your households' rancor to pure love. (2.3.87-88)

That was, after all, the result of Maria and Thomas Thynne's marriage. Though Thomas's father never forgave him or Maria's relatives, the marriage did neutralize the political strife of the two families. During her soliloquy, Juliet expresses the willingness to abandon the enmity of their families. Because she loves Romeo, she will "no longer be a Capulet" and she sees Romeo as an enemy in name only, a name which can be left behind (2.2.36). With this independent idea, she marries Romeo and her will to remain with the man she loves heals Verona's feuding families. 


\section{Chapter Two: She "lives in death"}

Feminist readers have many complaints about Much Ado About Nothing, and about Hero's character in particular. Those who look to Claudio's repudiation and his inability to mourn Hero's "death" without proof of her innocence see an oppressive patriarchy at work. In “The Public Repudiation of Hero," Nadine Page asks, "Why does Hero passively accept such treatment?" and concludes that in the Elizabethan world, "she had no alternative" $(739,744)$. In “'The Sign and Semblance of her Honor': Reading Gender Difference in Much Ado About Nothing," Carol Cook refers to "Hero's very blankness," suggesting that her character lacks any of her own motivation. Lisa Jardine reads Hero as a type of the patient and long-suffering Griselda character. Speaking of Hero and other Shakespearean heroines, Jardine writes that "the moment at which they shift into patient resignation and waiting, while the injustices done to them by their men folk are painstakingly resolved, they fall naturally into the postures expected of them; they become patient Griseldas" (184). There are three reasons that feminist readers find Hero's character difficult to accept. First, Hero's cousin, Beatrice, seems to outshine her in wit and her female energy seems to equal that of Benedick. Second, readers interpret Hero's silence in many of the scenes as an indication that she lacks her own will in the play. Third, Hero's feigned death, by absenting her from stage, appears to some critics to be a passive stance.

As with Juliet, mainstream critics have obscured the usefulness of the trick for Hero's character by focusing primarily on the implications of the ruse for Claudio, specifically, or the male patriarchal culture at large. Robert Grams Hunter's reading of the play in his book Shakespeare and the Comedy of Forgiveness established a tradition of considering the counterfeit death as a moment of forgiveness for the male character. Hunter argues that Hero's ability to return to life from the feigned death allows Claudio's penance and contrition to be fully 
recognized and social order to be restored. Janice Hays also sees the counterfeit death as a benefit to Claudio. In "Those 'soft and delicate desires': Much Ado and the Distrust of Women," Hays argues that Hero's feigned death is part of a ritual "testing and vindication" that helps the man develop trust and empathy. Feminist critics counter that the death may benefit Claudio, but that again it points to oppressive patriarchy and the victimization of the passive heroine. Carol Cook suggests that Hero's counterfeit death is one element in the play that reinforces the preeminence of masculine power in the play. Cook looks beyond Claudio to implicate all of male Messina, arguing that the men in the play "need Hero to be dead for reasons that have nothing to do with Claudio" (197).

In this chapter, I propose that Hero is not a passive, blank victim, but that she uses the feigned death to manage her social environment and achieve her desires. Like Juliet, Hero's primary desire is for marriage. In making this claim I do not suggest that patriarchal restrictions are non-existent in Messina. Rather, I argue that Shakespeare represents Hero as understanding the limitations she faces. Her character finds a way to create an identity that allows her to pursue her goal. As a result, Hero's feigned death helps her restore her sullied reputation and resume her role as a bride.

\section{I}

One way to gain an appreciation for Hero's personal agency is to review the source material Shakespeare used to develop her character and to look at analogues of other female characters' supposed deaths. This section presents an analysis of the Ariodante-Genevra plot of Ariosto's Orlando Furioso, generally credited as the source of the Hero-Claudio plot, and then compares Hero's character to the heroine in an analogue tale by Barnabe Riche. Hero's position 
may not seem enviable to us today, but when placed against the characterization in other tales, it becomes clear that Hero is far more capable and active than her fellow Early Modern heroines. Before I develop the contrasts between the source and Much Ado About Nothing, I will summarize the source for readers unfamiliar with its details. In the fifth canto of Orlando $\underline{\text { Furioso, }}$, Duke Polynesso, driven to hatred by jealousy, seeks to separate Genevra from her beloved, Ariodante. He arranges for Ariodante and his brother to see Polynesso and Genevra's maid, Dalinda, disguised as Genevra, in an illicit embrace. After witnessing Genevra's infidelity, the brokenhearted Ariodante flees the town. A week later a peasant reports Ariodante's sorrow and his suicide to Genevra. Ariodante's brother reveals Genevra's supposed involvement with Polynesso as the reason for Ariodante's suicide. By law, Genevra must be condemned to death, unless her innocence can be proven by combat. A mysterious knight appears in defense of Genevra. Polynesso is overthrown and confesses his crime. The mysterious knight is revealed to be the supposedly dead Ariodante.

Shakespeare's most obvious departure from his source is the reassignment of the counterfeit death from the hero to the heroine. Other significant departures include the removal of the defense of the woman by the man (either the man who believes he has been wronged, or any other chivalrous knight willing to defend her) and the punishment of death for the woman should the accusation against her not be proven false. Thus, unlike Genevra, who would have died without the appearance of the revived Ariodante, Hero must act on her own behalf to defend and restore her reputation. Audience members familiar with the source would have noticed Shakespeare's reassignment of the counterfeit death and the subtle strength and activity the change brings to Hero's character. 
By granting Hero the counterfeit death, the play reassigns the strategy of defense from the male character to the wronged woman herself. Genevra does no more than deny her guilt: "For still she stiffly stood in the denial/Of this that wrought her undeserved woe" (Ariosto 5.70.3-4). Hero protests her innocence and then feigns death in defense of herself. Claudio is not the heroic male who defends Hero. He witnesses what he believes to be her unchaste behavior and publicly repudiates her. His life, other than the dissolution of his betrothal to Hero, continues as before. Hero's cannot. She must either resolve the situation so that the truth is revealed, or be sent away.

Related to Hero's feigning death in her own defense, is the absence of a law that requires her death and the champion male defender. Certainly, the play has remnants of the death as punishment, but the final resolution for Hero, should she not be proven innocent, will be a sequestered existence, rather than physical death. The play also retains a notion of the male battle, but removes it as a requirement for the direct defense of the woman's life. Benedick pledges to Beatrice that he will challenge Claudio and thus, it may be argued that Benedick assumes the role of the male defender from the source poem. However, it should be noted that Benedick is not at first willing to kill Claudio and is only persuaded to act by Beatricemotivated by love and friendship for Beatrice, not by the desire to defend Hero (and his victory would not save her). In Much Ado About Nothing, Hero must act to save herself—no other character is available to act for her.

Hero's active agency becomes clear when she is compared with other analogous heroines, such as Agatha, another feigner of death and the principal female character in Barnabe Riche's tale, "Gonsoles and his Vertuous Wife Agatha." Agatha counterfeits death unknowingly and completely without consent. The tale's basic plot is this: Gonsales marries Agatha, loses 
interest in her, and pursues a local courtesan. Eager to rid himself of Agatha and marry the courtesan, Gonsales persuades his friend to provide a poison to kill Agatha. Gonsales's friend, who is in love with Agatha, instead provides a soporific potion that makes Agatha appear dead. The friend is present when Agatha revives and attempts to persuade her to break her marriage vows, but she refuses. Later, the courtesan overhears Gonsales talking about his role in Agatha's apparent murder and she reveals his crime to the authorities. Gonsales is sentenced to death, but Agatha arrives to save him at the final moment. Agatha and Gonsales live together the rest of their marriage "in good love and peace." The tale ends with the narrator's praise of Agatha's "chaste and constant mind . . .the excellencye of her virtue . . . [and her] constant faith and honest disposition" (251).

In this moralistic tale, Agatha's apparent death is entirely passive. A male character imposes the supposed death on her with the hope that it will enable him to fulfill his own desires. She is completely unaware of its arrangement until she revives with the friend. By contrast, the Friar proposes the counterfeit death for Hero, but he does not impose it on her without her knowledge. The trick in the play occurs as a response to accusations of infidelity, rather than as a challenge to Hero's fidelity. For Agatha, the trope of the counterfeit death becomes an extreme test of a woman's fidelity. Will Agatha remain faithful to the husband who attempted to murder her? Yes, and in fact, she does not reappear publicly until it becomes necessary to save her husband and reveal the truth about his attempt to murder her. Hero's reappearance occurs after the truth about her is known, not before. Here again, Hero saves herself; the other tales use the counterfeit death to save another character. Hero feigns death with the hope that it will resolve the injustice done to her. It may require her inaction, but it is not a resigned and patient act. 


\section{II}

As noted earlier, one of the common complaints about Hero is her silence and blankness. It is assumed that her silence indicates her passivity. Hero's relative lack of lines compared to Beatrice or other heroines, such as Juliet, makes it more difficult to discover Hero's desires and obscures her personal resolve in feigning death, but the play provides sufficient contexts with which to construct Hero's character and to understand her role in her feigned death. Other characters' responses to her and changes in her behavior in different social groups demonstrate that, despite her few words, Hero communicates what she wants. Hero wants a husband and she behaves intentionally to construct her identity to achieve her goal.

Hero has fewer than half the number of lines of Beatrice and two-thirds fewer than Juliet. $^{6}$ There are scenes where Hero is present onstage, but speaks no lines at all. Yet, she communicates effectively with her silence. For example, Hero speaks a single line in the first scene, but we learn from the other characters what Hero is effectively communicating with her silence. She is demure in the company of men and submissive to her father. As a result, Claudio perceives her as "a modest young lady" (1.1.158). In this way, Hero constructs a useful identity for herself which Claudio then verbalizes for the audience.

Some critics view this stylized feminine behavior as evidence of an oppressive patriarchy. Nadine Page argues that Hero represents "the ideal marriageable girl" for the period (740). Summarizing some of the qualities of the ideal wife, Page writes that the "ideal wife must be chaste; she must be the 'mirror' of modesty ... she must be altogether charming" and submissive, first to her father and then to her husband (740). I agree with Page that Hero represents the ideal marriageable girl, but I suggest that, far from having this identity forced on her, Hero purposely constructs this identity because she wants to be married. Hero's manners 
among the men are intentional; she is more talkative in the company of Beatrice and other women. She chatters freely with Ursula in the scene designed for Beatrice to overhear them speaking of Benedick, her lines long, fluid, and free (3.1). At the end of the play, once her marriage is secured, she acts freely in mixed company for the first time when she participates in revealing Beatrice's affection for Benedick (5.4).

Hero's actions reveal that she views a woman's marriage as an important accomplishment. Women today expect more than a fiscally-smart, arranged marriage, but, from Hero's point of view, a well-matched marriage is desirable and represented a significantly better alternative to a nunnery or spinsterhood (the alternatives the Friar later suggests, should the ruse of the counterfeit death fail). In a well-matched marriage, Hero will be financially supported and have an active role in respectable society. (For the true cynic, if she were lucky enough to be widowed early, she would even gain some independence and control of her estate.) Rather than criticize the system she operated within, I will show how Hero exercised her agency in her environment through another ruse she participates in - the deception to bring Beatrice and Benedick together.

The deception to draw Beatrice and Benedick together prepares Hero for the ruse of the counterfeit death and demonstrates her interest in marriage. She wishes a good marriage for her cousin, as she wishes it for herself. She tells the Prince, "I will do any modest office, my lord, to help my/cousin to a good husband" (2.1.254-5). Hero's longest speeches are related to the Beatrice-Benedick plot. Both her willingness to undertake such a task and her enthusiasm in carrying it out suggest that she believes marriage is important for a woman and that actively striving to bring it about is acceptable. The counterfeit death is another means to the same end for Hero. At the conclusion of the scene with Ursula when Beatrice is tricked into thinking 
Benedict is in love with her, Hero remarks that "loving goes by haps:/Some Cupid kills with arrows, some with traps" (3.1.105-6). She does not seem bothered by the use of deception to bring a couple together. Thus, we may also read her own counterfeit death deception as acceptable to her.

Hero counterfeits death with the possibility of two outcomes, either the restoration of her reputation and a rescheduled wedding day or a quiet banishment to escape the gossip and public humiliation. If Hero desires marriage, repairing her slandered reputation would be her first priority. She may indeed want a reunion with Claudio, the comedic ending of the play allows us to assume so; however, the true comedic end comes from the restoration of the knowledge of Hero's innocence to the community because without a public re-establishment of the truth of her purity, her future has few prospects. Nadine Page suggests that "[a]fter such a public defamation, regardless of her innocence, Hero, even with her father's help, could not make another match" (744). However, through the ruse, Hero is able to resume her wedding where it was abruptly cut short.

A close reading of the arrangement of the counterfeit death shows that the trick is as much concerned with Hero's reputation as it is with changing Claudio's mind. Note what is absent from the planned counterfeit death: first, it is not clear from the Friar's proposal how, once Claudio's contrition is secured, Hero will be revived and the couple reunited; second, the Friar gives no indication of how long she may be rumored dead. The Friar seems to have more of a plan for the failure of the trick than for its success. After explaining the ruse, the Friar assures the family that the trick will likely turn out better than he can project in explaining it; however, if not, Hero can always be sent away:

The supposition of the lady's death 
Will quench the wonder of her infamy:

And if it sort not well, you may conceal her,

As best befits her wounded reputation.

In some reclusive and religious life,

Out of all eyes, tongues, minds, and injuries. (4.1.237-42)

Hero has been injured by Claudio's repudiation and she has become an infamous woman because his words have wounded her reputation. As a result, others in the community have changed the way they see, speak, and think about her. She must repair her reputation in order to participate in the community again. To resume her identity, Hero needs the community to recognize her innocence, to see, speak, and think of her the way she truly is. Should the gossip prove too great and the efforts to restore her reputation fail, Hero can be sent away. In this sense, the counterfeit death again offers some sense of escape from an unpleasant situation, as it did for Juliet. However, I am proposing that Hero hopes for the revelation of the truth, rather than a means of escape.

\section{III}

Hero makes a striking foil to Juliet in several ways. Hero is obedient where Juliet is disobedient, demure where Juliet is verbose. Hero is both aided and thwarted by community where Juliet is isolated. Despite their differences, for both characters the need to counterfeit death is closely tied to sexual reputation. As I described in the previous chapter, Juliet uses the trick to attempt to escape a second marriage. Hero uses the trick to address the slander to her reputation. Others judge her guilt by appearances: Claudio and the Prince by the feigned scene of Borachio and Margaret; Leonato by her blushes during the repudiation. Only the Friar reads her 
appearance correctly; during the repudiation, the Friar sees a blush of innocence, not the blush of guilt.

The Friar, in suggesting the counterfeit death, attempts to provide similar heavenly intervention for Hero. The Friar refers to his own "reverence," "calling," and "divinity" as reasons for Leonato to believe his interpretation of Hero's blushes and his belief in her innocence (4.1.167). The Friar's position lends him authority to judge her spirit and to counsel the family. Only the Friar, as the heavenly representative, is able to discern the truth when the other men cannot. Hero is not the only woman to be misjudged by men. Anne Greene, whose real-life experience is recounted in A Wonder of Wonders (1651) and Newes from the Dead (1651), is misjudged, condemned to death, and then miraculously revives. Anne's revival is also attributed to heavenly intercession which is perceived to confirm Anne's innocence and to expose the mistake in judgment.

Anne Green's experience is this: While working as a maid at the house of Sir Thomas Read, Anne Greene became pregnant by Read's grandson. She delivered the baby in secret, a still birth, and hid the dead infant in the house. When the baby's body was discovered, Anne was accused of murdering the baby and condemned to death. Following her execution by hanging, Anne's body was delivered to a surgeon who wanted to use the body for anatomical dissection and study; however, when the doctor opened the coffin, Anne was breathing. With the doctor's care, Anne was fully restored to life and pardoned of her crime because of the miraculous nature of her experience. Newes from the Dead (1651) goes to some length to proclaim her innocence of the charge of murder, concluding that the revival was "a means to vindicate her from the foul stain of Murder, which, in most men's judgments (and, perhaps, Heaven itself also bearing witness) was so harshly charged upon her" (8). 
Anne Greene's example demonstrates the effectiveness of revival as restorative not only of the body, but also of the woman's reputation. Certainly, Anne Greene's situation differs greatly from Hero's. Anne did engage in unlawful sexual relations that resulted in a pregnancy. Hero does not. However, the salient element of the event is the impact of her death and revival in establishing her innocence (of the murder). Just as Anne Green's claim that the baby was stillborn was not believed, Hero's claims of her innocence are not believed by those with authority (the Prince, her father, and Claudio). In Anne's case, the revival was "a means to vindicate her from that foul stain of Murder" (Watkins 8). Hero's revival results from her vindication from Claudio's cruel repudiation and slander. The timing of the revival is different for Hero than for Anne. She cannot revive until she has been vindicated. Anne is vindicated as a result of the revival.

Hero's feigned death is similar to Anne Green's in that it relies distinctly on the judgment of others, both in its conception and in its ability to bring about the desired result. Though the play's characterization of Hero suggests that she desires marriage and thus would be willing to counterfeit death, it is difficult to gage her response to the Friar's plan because she has so few lines overall in the play and none in the scene after the Friar proposes the plan. She speaks just ten lines during the repudiation, many of them not even full lines, and eight lines during the discussion with her father, the Friar, Beatrice, and Benedick following the repudiation. Leonato consents to the counterfeit death for her, but her co-operation demonstrates her consent, though she does not speak it. As we saw in Act One, Scene One, she acts in character in this regard; her actions speak for her. Her final lines in the scene, from one of her longest speeches, show that she would accept death should the accusation be true, which suggests that counterfeiting death until it is proven false would be acceptable to her: 
They know that do accuse me; I know none.

If I know more of any man alive

Than that which maiden modesty doth warrant,

Let all my sins lack mercy! O my father,

Prove you that any man with me convers'd

At hours unmeet, or that I yesternight

Maintain'd the change of words with any creature,

Refuse me, hate me, torture me to death! (4.1.176-83)

In this speech Hero reasserts her innocence and modesty. Her language cleverly includes words that can be read as either sexual or as simple communication. "Conversed," for example, can imply sexual intercourse or speaking (OED). However, judging from Hero's silence in other scenes, her speech can be read as a protestation of her total modesty, which prevents her from even speaking in the company of "any man" when it is not appropriate. In this regard, acting inappropriately would seem entirely out of the range of her character. After proclaiming her innocence, Hero then addresses the men who currently hold her fate in hand, her father and the Friar. It is not clear whether she addresses Leonato, her earthly father, or the Friar, her spiritual father and the individual who asked her the identity of the man she was "accused of" being with by the Prince and Claudio (4.1.175). In either case, the speech is similar to Juliet's impassioned speech to the Friar where she is also willing to die. Juliet will assume the action ("And with this knife I'll help it presently"), but Hero defers the burden of proof and judgment to the male authorities (Rom. 4.1.54). Juliet tells the Friar that she would kill herself if he could not help her; Hero tells her father he can torture her to death if the accusation is true. We may read that and 
the absence of a protest as her consent to feign death, for until the accusation is proven false (a twist in justice) she will be dead.

As in Romeo and Juliet, it is the Friar who constructs the trick and its trappings.

However, in this play, he instructs the family members who are also participating in the trick. It is their responsibility to:

... publish it that she is dead indeed;

Maintain a mourning ostentation,

And on your family's old monument

Hang mournful epitaphs, and do all rites

That appertain unto a burial (4.1.203-7).

Hero's role in this performance is to "be secretly kept in," itself a kind of metaphoric burial or entombment from participation in regular society (4.1.202). Whatever rites of burial or entombment are performed seem to have taken place without the participation of the Prince and Claudio. In the next act, when Leonato and his brother meet Claudio and the Prince, Leonato tells them that Hero "lies buried with her ancestors . . . in a tomb" (5.1. 70). The rumor of her death is easily performed because she had fainted at the accusations made against her and was left apparently lifeless at the altar. No other information is provided and no other details are required to establish the lie. Her body, though critically important to the reason for the trick, participates in the deception through its absence. She has been secreted away, both literally and figuratively, her body absent and suspended until her innocence can be established.

\section{IV}

It is not until Borachio's confession that Hero's counterfeit death is effective. It is with the confession of Borachio that the audience feels the first sense of relief. Until this point, 
Claudio has been unmoved by the news of Hero's death and it seems that the ruse will not have the effect the Friar suggested:

... Then shall he [Claudio] mourn -

If ever love had interest in his liver -

And wish he had not so accused her:

No, though he thought his accusation true. (4.1.229-32)

In “"The Sign and Semblance of Her Honor': Reading Gender Difference in Much Ado About Nothing," Carole Cook argues that Hero's counterfeit death is a failure because it misses its intended target, Claudio. Cook points out that "[i]t is not until he learns of her innocence that Claudio's feeling changes ... and once in the possession of the 'truth' about Hero, he simply reverts to his initial image of her" (196). However, Hero's feigned death does move another character-who in turns affects Claudio, the Prince, and Leonato. Borachio, the actor in the deception that led Claudio and the Prince to believe in Hero's sensuality is moved by Hero's apparent death. If Claudio does not repent his reaction to the deceit until he hears the truth, Borachio is repentant of his participation in the deception. Dogberry's trying extraction of his confession makes possible the realignment of the public status of Hero's honor with the private truth; she is chaste and those who doubted it are shown their mistake. Borachio hears from the sexton during his cross-examination that "Hero was in this manner accused, in this very manner refused, and upon the grief of this suddenly/died" (4.2.61-3). Following this scene, he recounts his deed to the Prince and Claudio. He tells Leonato that he would "rather seal [his villainy] with [his] death than repeat it over to [his]/shame" (5.1.232-233).

Borachio's revelation causes all three men, even Leonato, who knows that Hero has not literally died, to acutely feel the loss of her life. The Prince asks Claudio, "Runs not this speech 
like iron through your/blood" (5.1.236-7). Claudio feels that he has "drunk poison whiles [Borachio] uttered it," and then Hero's “image doth appear/In the rare semblance that I lov'd it first" $(5.1 .238,243-4)$. The combination of the feigned death and Borachio's confession cause the change of heart in Claudio. Borachio's capture may not have had the same impact if Hero's supposed death had not been published. The sexton would not have been able to relate it to Borachio at the hearing and Borachio's remorse may have been less. Thus, the issue seems to be not the value of the death, but Claudio's nature which prevents him from being affected by her death while he still believes her guilty.

This moment also results in the arrangement of Claudio's penance, which points directly to the reasons Hero feigned death. Hero's concern with reputation and marriage are echoed in the penance Leonato exacts from Claudio. Leonato asks Claudio to do three things. First, he must tell everyone in Messina "how innocent she died;" second, memorialize her at the tomb; and third, marry his niece (5.1.274). The reversal of his repudiation will restore Hero's reputation in the community. It could be argued that the counterfeit death accomplishes nothing for Hero. Modern day readers might even argue that Hero gets a poor end, having to marry the man who so easily distrusted her and publicly dismissed her (thought not so poor an end as Agatha, who is happily reunited with the husband who attempted to murder her). However, Hero's counterfeit death has revealed the truth, cleared her reputation, and will allow her to marry, as Leonato's "niece" is revealed to be the revived Hero.

If readers are skeptical, Hero herself seems to believe that the experience has transformed her. When Hero reveals herself to Claudio, she identifies both herself and Claudio as changed: And when I liv'd, I was your other wife; And when you lov'd, you were my other husband. (5.4 60-1) 
Hero uses "other"- "distinct from that or those already specified or implied; different"—-to describe them in their former betrothal, suggesting that they have both undergone events that changed them and their relationship (OED). Claudio seems to misunderstand and rephrases his astonishment as "Another Hero" (5.4.62). "Another" suggests figuratively "a second in effect, though not in name or intention, a second in likeness of character or attributes; a counterpart to" (OED). ${ }^{7}$ Even when Leonato requires Claudio to marry his niece, he describes her as "[a]lmost the copy of my child that's dead" (5.1.281). "Almost the copy" supports the fundamental conclusion that the feigned death has changed something about Hero and that her progress has not been circular.

Hero clarifies the distinction: "One Hero died defil'd, but I do live,/And surely as I live I am a maid" (5.4.63-4). She is both other and another, distinct from the former Hero in her recent experience and yet, like her in her innocence. Her clarification reaffirms her reputation and the intactness of her chastity as part of her identity. She lives a maid—she never truly was otherwise. The emphasis on the difference between her former self and her revived self is remarkable in a character that speaks very little overall. The Prince and Leonato complete the dialogue that restores her. The Prince identifies her most literally as "The former Hero! Hero that is dead!" and then Leonato concludes, "She died, my lord, but whiles her slander liv'd" (5.4.65-6). This series of exchanges establishes Hero's revived identity and reconnects it with her former identity: that of a chaste maid ready for marriage. 


\section{Conclusion}

I have demonstrated that a combined cultural and close reading of the counterfeit deaths of Juliet and Hero changes our understanding of the heroines and their role in the plays. The counterfeit death in my reading serves as evidence of the heroine's agency, as a ruse she uses to escape or manipulate her circumstances. But, this thesis only begins the project. Shakespeare reuses the counterfeit death trope with other female characters. Juliet and Hero, as distinct heroines in separate genres, establish a strong argument that further exploration of the trope in other plays might yield promising results. My approach provides another avenue for understanding how women dealt with the patriarchal structure in place and suggests that, despite its negative aspects, women could adopt strategies that attempted to further their own goals.

Other instances that might be explored in this regard are Desdemona's brief revival from murder in Othello and Hermione's sixteen-year counterfeit death in The Winter's Tale. Although there is no evidence that Desdemona expressly chooses the counterfeit, Shakespeare's revisions to the source story, Cinthio's Hundred Tales, seem to help her accomplish something not granted in the source story. Hundred Tales does not include a counterfeit death at all. Shakespeare's revision gives Desdemona a voice after Othello thinks he has murdered her. This decision departs radically from the expectation set by the source story and further emphasizes Othello's misunderstanding of the female body—he misjudges her appearance and actions both in life and in death. Her opportunity to speak, to respond to Othello's action, shifts the focus back to Desdemona and her innocence in a way that the source story does not. Desdemona only has three lines, but in them she cryptically alludes to the false murder, her guiltless death, and answers that nobody has "done this deed" (5.2.126). In reviving and claiming her death as her own, she gains control of her experience and, though still ultimately a victim of Iago's strategy and Othello's 
weakness, the revision allows her to communicate briefly with Othello and Emilia which leads to the revelation of her innocence to Othello. Her lack of choice changes the impact of her apparent death and makes it seem more miraculous than Juliet's or Hero's because the device is not revealed from the outset. Although she dies, her brief revival does serve to reveal her innocence.

The sixteen year counterfeit death of Hermione in The Winter's Tale artfully centers the end of the counterfeit on the re-discovery of her body. The female body becomes the focal point and the counterfeit death is an attempt for the female character to gain control of how her body is perceived by others. This play's excesses, both Hermione's absence and Leontes's long mourning, are unusual. We cannot construct what Hermione did for the sixteen years she was presumed dead or why she chose to remain away so long. The text does suggest that her revival occurs because of the return of her daughter, Perdita. Hermione's first words are spoken to Perdita, though we hear from the other characters that she first embraces her husband. Her return as a statue is perhaps the most successful counterfeit, though because of the time lapse, the restoration remains poignant because of what has been lost.

Each instance of the counterfeit death expresses loss, and it is this loss that has caused critics to view the deaths negatively as part of the oppressive patriarchy. Without denying that the plays are difficult and the choices the characters face are often unpleasant, my reading complicates and thickens the experience so that the heroines' strengths become evident. Juliet is a willful and independent woman. The counterfeit death is another act to protect the marriage she has pursued. In my reading, Hero becomes an astonishingly shrewd character, one aware of what men want and perceive and whose silence is intentional, helping her to construct an identity to achieve the best marriage match she can. 


\section{Notes}

\footnotetext{
${ }^{1}$ In Narrative and Dramatic Sources of Shakespeare, Geoffrey Bulloughs states that “[u]ndoubtedly [Shakespeare's] main and perhaps sole source was Arthur Brooke's long poem
} 'The Tragicall History of Romeus and Juliet'” which was published in 1562 (274). The theme of the play was a popular one in Renaissance Italy and was adapted in several other works by Luigi da Porto, Bandello, and Pierre Boaistuau. Others argue for Shakespeare's familiarity with one or more of the other versions. For example, in "Shakespeare's Deviations from "Romeus and Juliet," Olin H. Moore argues that Shakespeare had access to Luigi da Porto’s novella.

${ }^{2}$ There are no archives for the Arches in the sixteenth century to determine the number of suits, but other studies indicate that the Winchester and Norwich dioceses heard about fourteen matrimonial suits each year (Wall 532).

${ }^{3}$ Swinburne's treatise was written in 1600 and, though it was not published until 1686, it circulated in manuscript form among lawyers (Callaghan 284).

${ }^{4}$ In Birth, Marriage \& Death: Ritual, Religion, and the Life-Cycle in Tudor and Stuart England, David Cressy writes that typically "no more than two or three days passed between the death of a person and the burial of a corpse" (426). The Friar seems to contract the preparation of the body to dressing her and placing rosemary on the corpse. Preparing the body "included washing, winding, and watching before taking the body to the church" (425). "The custom of 'watching' a corpse, that is, sitting up all night in the company of the dead body, was practiced by rich and poor with varying degrees of diligence ... 'Watching', at one level, secured yet another mark of respect to the deceased and his or her family, and provided a final period of intimate attendance before the body was publicly laid to rest. One practical benefit was to safeguard the 
corpse from tampering; another was to have someone on hand in case the body unexpectedly revived. For people who believed that the soul or spirit was not fully detached, and might in some way hover or linger during that liminal interval between death and interment, the experience of watching could be full of terrors" (Cressy 428). Henri Misson, a visiting FrenchSwiss who observed English burial practices, records that, after preparing the body, it was left for a few days " "to give the dead person an opportunity of coming to life again"” (qtd. in Cressy 454).

${ }^{5}$ Whether Shakespeare read this tale is unknown. However, it seems probable that he knew other tales like it. He was familiar with other tales by Riche published in the same collection, Riche,

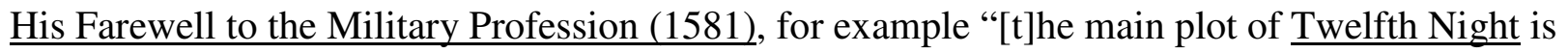
a version of Riche's 'Apolonius and Silla'” (Benson xxxii).

${ }^{6}$ Hero has 44 lines, Beatrice 106, and Juliet 118.

${ }^{7}$ For a reading that suggests that the play's progress is circular and that "Hero remains dead in her resurrection, as she is reappropriated to the mode of perception that killed her," see Carol Cook’s article “'The Sign and Semblance of Her Honor': Reading Gender Difference in Much Ado About Nothing" (200). 


\section{Works Cited}

“Another” Oxford English Dictionary (OED) Online. 2007. Rhode Island College Lib. 29 Jan. 2007. <http://www.oed.com>.

Ariosto, Ludovico. Orlando Furioso. Translated into English heroical verse by Sir John Harington (1591). Ed. Robert McNulty. Oxford: Clarendon-Oxford UP, 1986.

Brooke, Athur. "Romeus and Juliet (1562)." Narrative and Dramatic Sources of Shakespeare, Volume 1: Early Comedies, Poems, Romeo and Juliet. Ed. Geoffrey Bullough. London: Routledge and Kegan Paul, 1961.

Bullough, Geoffrey, ed. Narrative and Dramatic Sources of Shakespeare, Volume 1: Early Comedies, Poems, Romeo and Juliet. London: Routledge and Kegan Paul, 1961.

Callaghan, Dymnpa. "Introduction.” A Feminist Companion to Shakespeare. Ed. Dympna Callaghan. Blackwell Companions to Literature and Culture Ser. Malden, MA: Blackwell Publishers, 2000.

“Conversed” Oxford English Dictionary (OED) Online. 2007. Rhode Island College Lib. 16 Apr. 2007. $<$ http://www.oed.com>.

Cook, Carol. “'The Sign and Semblance of Her Honor’: Reading Gender Difference in Much Ado About Nothing." PMLA 101.2 (1986): 186-202.

Cressy, David. Birth, Marriage \& Death: Ritual, Religion, and the Life-Cycle in Tudor and Stuart England. Oxford: Oxford UP, 1999.

Döring, Tobias. Performances of Mourning in Shakespearean Theatre and Early Modern Culture. Basingstoke: Palgave Macmillan, 2006.

Fothergill, Robert A. "The Perfect Image of Life: Counterfeit Death in the Plays of Shakespeare and His Contemporaries." University of Toronto Quarterly 52.2 (1982-1983): 155-178. 
“A Full and True Relation Of a Maid (1680).” Early English Books Online. Brown U Lib. 10 Dec. $2007<$ http://eebo.chadwyck.com/home>.

Gittings, Clare and Peter C. Jupp, eds. Death in England: An Illustrated History. New

Brunswick: Rutgers UP, 2000.

Hays, Janice. "Those 'soft and delicate desires': Much Ado and the Distrust of Women.” The Woman's Part: Feminist Criticism of Shakespeare. Ed. Carolyn Ruth Swift Lenz et al. Urbana: U of Illinois P, 1980.

Hunter, Robert Grams. Shakespeare and the Comedy of Forgiveness. New York: Columbia UP, 1965.

Jardine, Lisa. Still Harping on Daughters: Women and Drama in the Age of Shakespeare. Sussex: The Harvester P, 1983.

Lenz, Carolyn Swift, Gayle Greene, and Carol Thomas Neely. “Introduction. The Woman's Part:Feminist Criticism of Shakespeare. Urbana: U of Illinois P, 1980.

Moisan, Thomas. "Rhetoric and the Rehearsal of Death: The 'Lamentations' Scene in $\underline{\text { Romeo }}$ and Juliet." Shakespeare Quarterly 34.4 (1983): 389-404.

“Other" Oxford English Dictionary (OED) Online. 2007. Rhode Island College Lib. 29 Jan. 2007 $<$ http://www.oed.com>.

Page, Nadine. “The Public Repudiation of Hero.” PMLA 50.3 (1935): 739-744.

Phillippy, Patricia. Women, Death and Literature in Post-Reformation England. Cambridge: Cambridge UP, 2002.

Playfere, Thomas. The Meane in Mourning (1595). Early English Books Online. Brown U Lib. 10 Dec. 2007 <http://eebo.chadwyck.com/home>.

Pollard, Tanya. “'A Thing Like Death’: Sleeping Potions and Poisons in Romeo and Juliet and Antony and Cleopatra. Renaissance Drama. 32 (2003): 95-121. 
Riche, Barnabe. "Of Gonsales and His Vertuous Wife Agatha." Italian Tales from the Age of Shakespeare. Ed. Pamela Benson. London: J.M. Dent; Vermont: Charles E. Tuttle, 1996. 236-251.

Romack, Katherine M. "Margaret Cavendish, Shakespeare Critic.” A Feminist Companion to

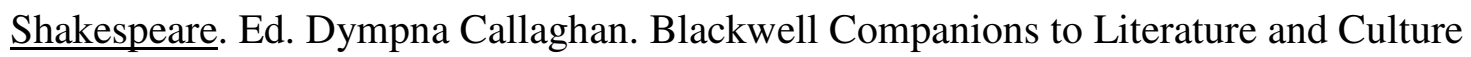
Ser. Malden, MA: Blackwell Publishers, 2000.

Shakespeare, William. Much Ado About Nothing. The Arden Shakespeare Complete Works. Ed. Richard Proudfoot, Ann Thompson, and David Scott Kastan. London: Thomson Learning, 2006.

- - . Romeo and Juliet. The Arden Shakespeare Complete Works. Ed. Richard Proudfoot, Ann Thompson, and David Scott Kastan. London: Thomson Learning, 2006.

Swinburne, Henry. "From A Treatise on Spousals." Romeo and Juliet: Texts and Contexts. Ed. Dympna Callaghan. Boston: Bedford/St. Martin's, 2003.

Wall, Alison. "For Love, Money, or Politics? A Clandestine Marriage and the Elizabethan Court of Arches.” The Historical Journal 38.3 (1995): 511-533.

Watkins, Richard. Newes from the dead. 1651. Early English Books Online. Brown U Lib. 10 Dec. $2007<$ http://eebo.chadwyck.com/home>.

A Wonder of Wonders. (1651). Early English Books Online. Brown U Lib. 10 Dec. 2007 $<$ http://eebo.chadwyck.com/home>. 